\title{
Bibliographical Scholarship in the United States, 1949-1974: A Review
}

\begin{abstract}
The period from 1949 through 1974 has been a significant one in the field of analytical bibliography in the United States. American writers have helped to establish new standards of editorial procedure and bibliographical description, have refined bibliographical techniques, and have applied those principles and techniques to subjects as diverse as early printing and twentieth-century literature. As part of this effort they have studied all the aspects of the history of the printed book, particularly in the United States. This review attempts to suggest, by citation of major books and articles and by example, the range and quality of the work accomplished.
\end{abstract}

\begin{abstract}
A lthough no one would suggest that the year 1949 marked the beginning of analytical bibliography in the United States, the appearance in that year of Fredson Bowers' Principles of Bibliographical Description and Curt F. Bühler, James G. McManaway, and Lawrence C. Wroth's Standards of Bibliographical Description did mark a turning point in the field. The purpose of this review is to note, specifically or by example, the more significant work in analytical bibliography and the history of the printed book accomplished in the United States from 1949 through 1974, wherever that work may have been published.

More complete bibliographical information on books and articles mentioned
\end{abstract}

Howell J. Heaney is rare book librarian of the Free Library of Philadelphia. This article is based on a paper delivered at a meeting of the Committee on Rare and Precious Books and Documents at the Fortieth General Council Meeting of the International Federation of Library Associations, in Washington, D.C., in November 1974. in the course of this paper is given in the bibliography at its conclusion.

The scope of the review is that of the annual "Selective Check List of Bibliographical Scholarship" launched by Fredson Bowers with the list for 1949 in the third volume of Studies in Bibliography. ${ }^{1}$ This means that emphasis is put on "primary investigations dealing with printing and publishing history, and bibliographical treatment of authors and their books, together with such critical or textual studies as are based on bibliographical evidence or the interpretation of basic documents," and, for the period of the later Renaissance to the present, on English and American literature and American history. This is to leave for review by another writings on bibliography in the broadest sense, of which Archer Taylor's A History of Bibliographies of Bibliographies (1955), Book Catalogues: Their Varieties and Uses (1957), and Catalogues of Rare Books: A Chapter in Bibliographical History (1958) are striking examples, and the important works of critical enumerative bib- 
liography published in the past twentysix years, works of the sort called by Stanley Pargellis "the kind the great innovators began."

In general, the framework for considering the books and articles discussed here is the outline of $A B H B$ : Annual Bibliography of the History of the Printed Book and Libraries, ${ }^{4}$ as adapted from Bibliography in Britain.

Finally, if the reader is to retain a sense of balance, he must remember that the contribution of scholars in the United States is only part of a broad and continuing effort to understand the history of books more fully and to make bibliography a more effective tool of scholarship.

\section{General Works}

The continuity of that effort is evident in the two books already mentioned. Fredson Bowers' Principles of Bibliographical Description is a vigorous and exhaustive extension of the work of McKerrow and Greg. With broader application than to early English literature, it is a direct answer to James G. McManaway's proposals for descriptive bibliography in his essay in Standards of Bibliographical Description: "general agreement that the purpose of bibliography is to describe the ideal copy of each book after the examination of every surviving copy"; "a uniform terminology" with "a precise definition of terms, particularly state, issue and edition"; and "a generally accepted formulary of collation." 5

The reaction to Bowers' stand then is evident in the three essays in Standards of Bibliographical Description. Curt F. Bühler points out that the incunabulists had long since established a universally accepted system of description and gently but firmly suggests that the general application of the Greg-Bowers formulary and shorthand would present difficulties. McManaway, although in agreement with Bowers, devotes most of his essay to the consideration of printing house practice and its meaning for the bibliographer and editor. Lawrence C. Wroth expresses a strong feeling that, at least in the field of Americana, exhaustive bibliographical description would be a misapplication of time and energy subject to the law of diminishing return, a text on which Herman W. Liebert expands in Bibliography Old \& New (1974).

In the years since the appearance of his Principles, Bowers has been equally active in three areas of bibliographical scholarship. He has refined those principles, most notably in "Bibliography, Pure Bibliography, and Literary Studies" (1952), "Purposes of Descriptive Bibliography, with Some Remarks on Methods" (1953), and "Bibliography Revisited" (1969). He has written on "Some Relations of Bibliography to Editorial Problems" (1950), Bibliography and Textual Criticism (1964), and "Multiple Authority: New Problems and Concepts of Copy-Text" (1972). He has applied the principles he has set down in work as diverse as his editions of The Dramatic Works of Thomas Dekker (19531961) and The Dramatic Works in the Beaumont and Fletcher Canon (19661970), and Whitman's Manuscripts: “Leaves of Grass" (1860), a Parallel Text (1955) and The University of Virginia Edition of the Works of Stephen Crane (1969- ).

W. W. Greg's pioneer work on the rationale of copy-text and the calculus of variants has been carried forward by Vinton A. Dearing's A Manual of Textual Analysis (1959) and Principles and Practice of Textual Analysis (1974), Paul Baender's "The Meaning of Copy-Text" (1969), and G. Thomas Tanselle's "The Meaning of Copy-Text: A Further Note" (1970), with a growing attention to the problems and variants presented by different periods and circumstances.

Editorial procedure has been discussed by editors of particular works in their introductions, by American contributors to the conferences on editorial procedure at the University of Toronto, and, among others, by R. C. Bald in his "Editorial Problems-A Preliminary Survey" (1950), by Cyrus Hoy in "On Editing Elizabethan Plays" (1972), by William B. Todd in "Bibliography and the Editorial Problem in the Eighteenth Century" (1951), by Fredson Bowers in "Some Principles for Scholarly Editions of Nineteenth-Century American Authors" (1964), and more re- 
cently by James E. Thorpe in Principles of Textual Criticism (1972) and by Matthew J. Broccoli and others in The Author's Intention (1972). Indeed, in "The SCADE Series: Apparatus for Definitive Editions" (1973) Bruccoli describes the extension of the procedure to the publication of the apparatus only, without the text, for definitive editions of works in copyright or works that it is not feasible to republish. All these deal with the field of literature, but Edwin Wolf, 2nd, has reminded us in "Evidence Indicating the Need for Some Bibliographical Analysis of American Printed Historical Works" (1969) that the Americanist can profit from attention to the history of his text.

Articles like that of James B. Meriwether and Joseph Katz, "A Redefinition of 'Issue" " (1972); William B. Todd's "Observations on the Incidence and Interpretation of Press Figures" (1950) and "Press Figures" (1953); and G. Thomas Tanselle's "The Identification of Type Faces in Bibliographical Description" (1966), "The Recording of Press Figures" (1966), "A System of Color Identification for Bibliographical Description" (1967), "The Use of Type Damage as Evidence in Bibliographical Description" (1968), "Copyright Records and the Bibliographer" (1969), "The Bibliographical Description of Patterns" (1970), "The Bibliographical Description of Paper" (1971), "Book-Jackets, Blurbs, and Bibliographers" (1971), and "Bibliography and Science" (1974) suggest a further book in the field of bibliographical description based on the work of these and other authorities in the past twenty-six years. Its author would draw heavily on the publications surveyed in Tanselle's "The Periodical Literature of English and American Bibliography" (1973), and would, hopefully, find useful "The Selective Check List of Bibliographical Scholarship for 1949" through that for $1972^{6}$ and the volumes of ABHB: Annual Bibliography of the History of the Printed Book and Libraries for 1970 and following years.

\section{INCUNABULA}

The contribution of the United States to the study of incunabula from 1949 through 1974 has been distinguished and varied.
Curt F. Bühler's Rosenbach lecture on incunabula printed in Standards of Bibliographical Description (1949) modestly suggested modifications in the standards long since established for his field, his The University and the Press in Fifteenth-Century Bologna (1958) centered on a given place, and his The Fifteenth-Century Book: The Scribes, the Printers, the Decorators (1960) on the transition from the manuscript to the printed book. As a happy tribute, his major articles to 1966 have been collected and published by the Grolier Club in Early Books and Manuscripts (1973). Frederick R. Goff's studies have ranged from "The Four Florentine Editions of Savonarola's Predica dellarte del bene morire" (1950) to The Permanence of Johann Gutenberg (1971), with Incunabula in American Libraries: A Third Census (1964) and its Supplement (1972) his major work. Rudolf Hirsch's contributions have been regular, many building toward his Printing, Selling and Reading, 1450-1550 (1967) and its second printing (1974) with a supplemental annotated bibliographical introduction.

The acquisition by the Morgan Library early in 1954 of the Romont copy of the Missale speciale Constantiense generated a literature as to its date sufficient to support an entirely separate survey. Allan Stevenson's conclusions, based on his view of the manufacture, distribution, and use of paper in the mid-fifteenth century, are most fully stated in The Problem of the "Missale speciale” (1967). Curt F. Bühler's appear in a series of articles, including "The Constance Missal and Two Documents from the Constance Diocese" (1956), "Who Printed the Missale speciale Constantiense?" (1957), "Another View of the Dating of the Missale speciale Constantiense" (1959), and "Last Words on Watermarks" (1973), an essay of broad application which concludes with the suggestion that "it would seem wise-at least for the immediate present-to treat the evidence that watermarks may provide for dating incunabula with some caution."

Hellmut Lehmann-Haupt has given us Peter Schoeffer (1950) and Gutenberg and the Master of the Playing Cards (1966) with its ingenious theory as to Gutenberg's 
experiments toward the mechanical decoration of his Bible. Elizabeth L. Eisenstein has examined the effects of the invention of printing in "Some Conjectures about the Impact of Printing on Western Society" (1968) and "The Advent of Printing and the Problem of the Renaissance" (1969). Walter L. Heilbronner's Printing and the Book in Fifteenth-Century England: A Bibliographical Survey (1967) is a most helpful annotated guide to bibliographies and critical works in a special segment of the field.

A score of lists, including Christopher U. Faye's Fifteenth Century Printed Books at the University of Illinois (1949), Dorothy M. Schullian and Francis E. Sommer's A Catalogue of Incunabula and Manuscripts in the Army Medical Library (1949), Phyllis W. G. Gordan's Fifteenth-Century Books in the Library of Howard Lehman Goodhart (1955), and Thomas E. Marston and Leon Nemoy's Incunabula in the Yale University Libraries (1955), bridged the gap between Margaret Bingham Stillwell's Incunabula in American Libraries: A Second Census (1940) and Goff's third census of 1964. The publication of Stillwell's The Awakening Interest in Science during the First Century of Printing (1970), a survey of the more important publications in mathematics, medicine, natural science, physics, and technology, and her The Beginning of the World of Books, 1450 to 1470 (1972), a chronological ordering of the books of the first twenty years of printing in Europe, saw the dream of a lifetime of work with early printed books realized.

\section{SixTEENTH- AND \\ Seventeenth-Century Books}

Studies like Stillwell's are dependent on the existence of basic guides, and here the student of the book in the sixteenth and even the seventeenth and eighteenth centuries is at a disadvantage as compared with the incunabulist. Specialization in even the basic listing of what was printed after 1500 , whether by country and region or by subject, is desirable, perhaps even inevitable, and the past twenty-six years have seen the publication of a number of such lists as well as work toward the revision of lists already published. William A. Jackson reported on the progress of his revision of Pollard and Redgrave in "The Revised
STC" (1955), and Katharine F. Pantzer wrote in "The Serpentine Progress of the STC Revision" (1968) on her continuation of the work after Jackson's death. The third volume of Donald G. Wing's Short-Title Catalogue . . 1641-1700 appeared in 1951, and the first volume of the revision, on which he was at work at the time of his death, was published in 1972.

Volumes such as Paul G. Morrison's Index of Printers, Publishers and Booksellers in ... "A Short-Title Catalogue . . 14751640" (1950), William Warner Bishop's A Checklist of American Copies of "ShortTitle Catalogue" Books (2d ed., 1950), and Edwin Wolf, 2nd's A Check-List of the Books in The Library Company of Philadelphia in and Supplementary to Wing's "Short-Title Catalogue, 1641-1700" (1959) have expanded the usefulness of both Pollard and Redgrave and Wing and helped to carry us over from edition to edition of the bibliographies themselves. For the continent The Rosenwald Collection: A Catalogue (1954), edited by Frederick R. Goff and supplemented by periodic reports on additions (principally in the Quarterly Journal of the Library of Congress), includes important sections. Two parts of the proposed series of full-dress catalogs of books and manuscripts in the Department of Printing and Graphic Arts of the Harvard College Library have also appeared, Ruth Mortimer's French 16th Century Books (1964) and her Italian 16th Century Books (1974).

\section{PAPER AND PAPERMAKING}

Dard Hunter and Allan Stevenson were the major writers in the United States on paper and papermaking in the twenty-six years between 1949 and 1974. If Stevenson was sometimes inclined to press his view of the dating of books on the basis of paper with more vigor than caution, he certainly advanced bibliography by his insistence, in essays such as his Observations on Paper as Evidence (1961) and the introduction to the second volume of the catalog of Hunt's botanical books (1961), that paper be taken into account in bibliographical studies and noted in bibliographical descriptions. He not only refined the tools at our disposal for the study of paper, as in his edition of Briquet (1968), but also gave us a model of the application of his 
views in the portion of the Hunt catalog he compiled. Dard Hunter's magnificent privately printed Papermaking by Hand in America (1950) was, happily, followed by an expansion of the text made available at moderate cost, Papermaking in Pioneer America (1952). The extension of his work will depend on a series of regional studies such as W. C. Adams' "History of Papermaking in the Pacific Northwest" (1951) and Marcus A. McCorison's "Vermont Papermaking, 1784-1820" (1964) and his "Addenda" to that article (1965).

\section{Printing, Typefounding, and Presses}

As with paper, the interest of American writers in typefounding and the history of presses and press making has been largely engaged by American subjects. Lawrence C. Wroth's revised edition of his Abel Buell of Connecticut (1958) enlarged a work first published in 1926, while Rollo G. Silver's Typefounding in America, 1787-1825 (1965) and The American Printer, 17871825 (1967) broke new ground. Hopefully, studies such as his "Efficiency Improved: The Genesis of the Web Press in America" (1970) will build toward books extending his earlier work. Jacob Kainen's George Clymer and the Columbian Press (1950) and Richard E. Huss' The Development of Printers' Mechanical Typesetting Methods, 1822-1925 (1973) stand at the beginning and end of the period under review, the one an account of the first major American improvement of the printing press and the other of the sometimes painful progress toward what must have been the dream of every master printer, if not of every compositor, from the time of Gutenberg.

\section{UNITED STATES IMPRINTS}

The listing of books about America, including those on what is now the United States, antedates the founding of the republic by almost a century and a half. The listing of the imprints of what is now the United States followed our independence, and may be traced from the work of Isaiah Thomas, as a collector and writer on the history of printing in America, through the bibliographies of Hildeburn, Seidensticker, and Evans to the present.

Indeed, Charles Evans' great effort to list our imprints from the earliest of 1639 through those of 1820 was rounded at 1800 with the publication of volume 13 of the American Bibliography (1955), the work of Clifford K. Shipton, seventy-five years after Evans had begun gathering material and fifty-two years after the appearance of the first volume of his bibliography. Volume 14, an author-title index by Roger P. Bristol, was published four years later, and Bristol's Index of Printers, Publishers, and Booksellers Indicated by Charles Evans in His "American Bibliography" in 1961. Shipton and James E. Mooney's alphabetical short-title Evans was published in 1969. Bristol's Supplement to Charles Evans' "American Bibliography" appeared in 1970, his index to the supplement the following year, and his first list of additions and corrections in 1972.

Roughly the same years saw the publication of the volumes of Ralph R. Shaw and Richard H. Shoemaker's American Bibliography: A Preliminary Checklist for 1801 [-1819] (1958-1966) and those of Shoemaker's A Checklist of American Imprints for 1820 [-1829] (1964-1973), the volumes for the last four years compiled with the assistance of Gayle Cooper, and two volumes of indexes by $\mathbf{M}$. Frances Cooper. A volume for 1830, compiled by Gayle Cooper, appeared in 1972 . The work is to be continued by Scott Bruntjen, Roger C. Greer, Michael H. Harris, and William A. Stoppel, with each of them responsible for a decade from the 1830s through the 1860s.

The efforts at listing the imprints of particular states and cities which began with Evans' predecessors were given special impetus during the 1930s by the work of the American Imprints Inventory of the Historical Records Survey under the direction of Douglas C. McMurtrie. The material gathered by the American Imprints Inventory workers, despite its limitations, has served as a guide to workers in the same field since. The latest volume published directly from the American Imprints Inventory files is the Check List of Wisconsin Imprints, 1864-1869 (1953), but for almost twenty years, beginning in 1951, students in the Department of Library Science of the Catholic University of America wrote master's theses based on short runs of the cards in the Inventory files preserved at the Library of Congress. 
More significantly, the influence of both McMurtrie and the Inventory carried over into the four volumes issued under the auspices of the Committee on Bibliographies of American Imprints of the Bibliographical Society of America (the last of them was Lester Hargrett's Oklahoma Imprints, 1835-1890, published in 1951), and a score of other bibliographies from George W. Belknap's McMurtrie's “Oregon Imprints": A Supplement (1951) to his Oregon Imprints, 1845-1870 (1968). Among like publications of the past twenty-six years special mention should be made of John Alden's Rhode Island Imprints, 17271800 (1950), Cecil K. Byrd and Howard H. Peckham's A Bibliography of Indiana Imprints, 1804-1853 (1955), Marcus A. McCorison's Vermont Imprints, 1778-1820 (1963) with its supplement (1968), and Byrd's A Bibliography of Illinois Imprints, 1814-1858 (1966), any one of which would serve as a model for a similar bibliography.

Of broader scope than any of these is Thomas W. Streeter's Bibliography of Texas, 1795-1845 (1955-1960), for its two volumes on Texas imprints include a full account of the newspapers published in Texas before 1846, with locations of extant files; its third volume is devoted to Mexican imprints on Texas; and its fourth and fifth volumes are devoted to imprints on Texas printed in the United States and Europe. The results of his work justified the more than thirty years Streeter devoted to it, and his introductions and notes raise the finished bibliography to the level of first-rate historical writing.

Marjorie L. Crandall's Confederate Imprints: A Check List Based Principally on the Collection of the Boston Athenaeum (1955) and Richard B. Harwell's More Confederate Imprints (1957) and Confederate Imprints in the University of Georgia Libraries (1964) are more general than the bibliographies of the imprints of particular states, and essays such as Frederick R. Goff's "Early Printing in Georgetown (Potomak), 1789-1800" (1958) continue the tradition of localized studies pursued so effectively by McMurtrie. Zoltán Haraszti's The Enigma of the Bay Psalm Book (1956) is an example of the result of close attention to an important book. Klaus G. Wust's "German Printing in Virginia: A Check
List, 1789-1834" (1953) and Walter Klinefelter's "The ABC Books of the Pennsylvania Germans" (1973), and James H. Fraser's "Indian Mission Printing: A Bibliography" (1968) and his "Indian Mission Printing in Arizona: An Historical Sketch and Bibliography" (1969) are examples of attention to printing for special groups. Dorothea N. Spear's Bibliography of American Directories through 1860 (1961) and Milton Drake's Almanacs of the United States (1962) are examples of attention to special classes of publications.

While the listing of private press books has not been as regular in this country as in England, James Lamar Weygand has given us news and reviews of such presses over the years in the American Book Collector, and bibliographies and accounts of private presses by others, many of them privately printed, have included Dorothy and David Magee's Bibliography of the Grabhorn Press, 1940-1956, with a CheckList, 1916-1940 (1957), Herbert Cahoon's The Overbrook Press Bibliography, 19341959 (1963), Norman H. Strouse's The Passionate Pirate (1964) on Thomas Bird Mosher, and Benton L. Hatch's A Check List of the Publications of Thomas Bird Mosher (1966).

\section{Book Illustration}

In the study of book illustration, as in other fields, scholarly publication follows on the gathering of adequate collections. Three collections have had a special influence on American studies of illustration in the past twenty-six years: Lessing J. Rosenwald's, given to the Library of Congress; Philip Hofer's, given to Harvard; and Sinclair Hamilton's, given to Princeton. The catalogs of the first two have already been cited here. Hofer's collection has supported numerous publications, including his own Baroque Illustration: A Short Survey (1951).

The catalog of Hamilton's collection, Early American Book Illustrators and Wood Engravers, 1670-1870 (1958), has been extended by a supplement published in 1968 . The plan of his catalog-with its division between books published prior to the nineteenth century considered chronologically and those of the nineteenth century considered under the names of their illustra- 
tors, with accounts of the work of the artists of both periods-makes the volumes much more than a guide to the collection.

Among the individual figures on whom detailed studies have appeared are Paul Revere (Clarence S. Brigham's Paul Revere's Engravings, 1954), Hablôt K. Browne (Albert Johannsen's Phiz. Illustrations from the Novels of Charles Dickens, 1956), and Blake (including Geoffrey Keynes and Edwin Wolf, 2nd's William Blake's Illuminated Books: A Census, 1953, and numerous papers by G. E. Bentley, Jr., Charles Ryskamp, and others).

\section{BoOKBINDING}

Although Dorothy Miner's remarkable The History of Bookbinding, 525-1950 A.D.: An Exhibition (1957) showed the range of bindings available in this country, in the study of binding, as in the study of printing, American writers have been principally concerned with American work. Michael Papantonio, with Hannah D. French and Carol and Willman Spawn, has given us Early American Bookbindings from the Collection of Michael Papantonio (1972), a fully illustrated and annotated catalog of examples of leather bindings from 1669 to 1864. The 1941 edition of Bookbinding in America by Hannah D. French, Joseph W. Rogers, and Hellmut Lehmann-Haupt was reprinted in 1967, with bibliographical supplements covering the literature of the twenty-five years from 1941 to 1967 added to each of its three sections. Lawrence S. Thompson has written on "Hand Bookbinding in the United States since the Civil War" (1954), and C. Clement Samford and John M. Hemphill, II, have given us a pioneer study, Bookbinding in Colonial Virginia (1966).

French has described the work of Andrew Barclay (in "The Amazing Career of Andrew Barclay, Scottish Bookbinder, of Boston," 1961), John Roulstone (in "John Roulstone's Harvard Bindings," 1970), and Caleb Buglass (in "Caleb Buglass, Binder of the Proposed Book of Common Prayer, Philadelphia, 1786," 1970); and the Spawns the work of Robert Aitken (in "The Aitken Shop: Identification of an Eighteenth-Century Bindery and Its Tools," 1963) and Francis Skinner (in "Francis Skinner, Bookbinder of Newport: An Eigh- teenth Century Craftsman Identified by His Tools," 1965). Frederick B. Adams, Jr.'s Bookbinding by T. J. Cobden-Sanderson: An Exhibition (1969) is a striking example of what can be accomplished in a small space.

Finally, Joan St.C. Crane in her series on "Rare and Seldom-Seen Dust Jackets of American First Editions," beginning in Serif 7 (1970), and G. Thomas Tanselle in his "Book-Jackets, Blurbs, and Bibliographers" (1971) have redirected our attention to the importance of book jackets as bibliographical evidence.

\section{Publishing AND Bookselling}

In the field of publishing, which is closely related to that of printing, discussed earlier, the publications of the period under review are very nearly bracketed by the appearance of the second edition of The Book in America: A History of the Making and Selling of Books in the United States (1951) by Hellmut Lehmann-Haupt, Lawrence C. Wroth, and Rollo G. Silver, and John Tebbel's A History of Book Publishing in the United States, vol. I, The Creation of an Industry, 1630-1865 (1972). Books and essays such as LeRoy Hewlett's "James Rivington, Tory Printer," in Books in America's Past (1966), edited by David Kaser, Kaser's own Messrs. Carey \& Lea of Philadelphia (1957), and Carl J. Weber's The Rise and Fall of James Ripley Osgood (1959) have shown us publishers of the eastern seaboard in different eras.

Bertram W. Korn's "Benjamin Levy: New Orleans Printer and Publisher" (1960), supplemented by his "Additional Benjamin and Alexander Levy Imprints" (1968), Kaser's Joseph Charless: Printer in the Western Country (1963), Albert H. Greenly's A Bibliography of Father Richard's Press in Detroit (1955), Walter Sutton's The Western Book Trade: Cincinnati as a Nineteenth-Century Publishing and Book Trade Center (1961), Lota M. Spell's Pioneer Printer: Samuel Bangs in Mexico and Texas (1963), and Madeleine B. Stern's Imprints on History: Book Publishers and American Frontiers (1956) have taken us farther west.

Warren S. Tryon and William Charvat's The Cost Books of Ticknor and Fields and Their Predecessors, 1832-1858 (1949) and 
Kaser's The Cost Book of Carey and Lea, 1825-1838 (1963) have shown us the publisher in his counting house. John H. Powell's The Books of a New Nation: United States Government Publications, 1774-1814 (1957) exhibited the new federal government as publisher; and C. Harvey Gardiner's Prescott and His Publishers (1959), an author's relationship with his publishers. A host of possible subjects for further study is suggested by directories such as A Directory of the Book-Arts and Book Trade in Philadelphia to 1820, Including Painters and Engravers (1950) and A Directory of Printing, Publishing, Bookselling and Allied Trades in Rhode Island to 1865 (1958), both by H. Glenn and Maude C. Brown, and A Directory of the St. Louis Book and Printing Trades to 1850 (1961) by David Kaser. Much useful work of the same sort remains to be done.

With some exceptions-Clarence S. Brigham's “American Booksellers' Catalogues, 1734-1800" in Essays Honoring Lawrence C. Wroth (1951) and John Alden's "Pills and Publishing: Some Notes on the English Book Trade, 1660-1715" (1952), and a number of studies already cited in connection with publishing-the more important accounts of bookselling to appear in the past twenty-six years have been biographies or autobiographies. Henry Stevens' Recollections of James Lenox was republished in 1951, edited by Victor Hugo Paltsits, and Wyman W. Parker has enlarged our knowledge of Stevens through his Henry Stevens of Vermont (1963). Edwin Wolf, 2nd, and John F. Fleming in Rosenbach: A Biography (1960) have shown us "Dr. R," warts and all, if not all warts. Among the autobiographies are Charles P. Everitt's Adventures of a Treasure Hunter (1951), David A. Randall's Dukedom Large Enough (1969) David Magee's Infinite Riches (1973) and Leona Rostenberg and Madeleine B. Stern's Old \& Rare: Thirty Years in the Book Business (1974).

E. Millicent Sowerby's lively Rare People and Rare Books (1967) must be conceded to England, although much of her life has been spent in the United States. Although they deal with private and institutional collecting as well as bookselling, two masterly articles by Gordon N. Ray should also be mentioned here: "The Changing World of Rare Books" (1965) and "The World of Rare Books Re-examined" (1974).

In the area of the legal, economic, and social aspects of the history of books, Frederick R. Goff has given us an account of "The First Decade of the Federal Act for Copyright, 1790-1800," in Essays Honoring Lawrence C. Wroth (1951). Other volumes are Frederick S. Siebert's Freedom of the Press in England, 1476-1776 (1952), and Lyman R. Patterson's Copyright in Historical Perspective (1968). Leona Rostenberg's The Minority Press and the English Crown: A Study in Repression, 1558-1625 (1971) extends her researches in English publishing in the sixteenth and seventeenth centuries.

\section{JoURNALISM}

In the area of newspapers and journalism the appearance of Clarence S. Brigham's Additions and Corrections to "History and Bibliography of American Newspapers, 1690-1820" (1961), and volume 4 of Frank Luther Mott's A History of American Magazines (1957), covering the period 18851905 , reminded us of the tremendous debt we already owed those two scholars. As with imprints generally, so with newspapers, the bulk of the material to be dealt with after the earliest period has suggested regional studies such as Muir Dawson's History and Bibliography of Southern California Newspapers, 1851-1876 (1950), and "A Bibliography of Newspapers in Fourteen New York State Counties" (1971 and following) by Sylvia G. Faibisoff and others.

Newspapers and periodicals together have been treated by language, as in Raymond R. MacCurdy's A History and Bibliography of Spanish-Language Newspapers and Magazines in Louisiana, 1808-1949 (1951) and Karl J. R. Arndt and May E. Olson's Die deutschsprachige Presse der Amerikas, 1732-1968: Geschichte und Bibliographie (1973), or by other special aspects, as in Gaylord P. Albaugh's "American Presbyterian Periodicals and Newspapers, 1752-1830, with Library Locations" (1963 and following) and Alfred L. Bush and Robert S. Fraser's American Indian Periodicals in the Princeton University $\mathrm{Li}$ brary: A Preliminary List (1970).

Histories of particular newspapers and 
periodicals have included David Ayerst's The "Manchester Guardian": Biography of a Newspaper (1971), Richmond P. Bond's The "Tatler": The Making of a Literary Journal (1971), Spencer L. Eddy, Jr.'s The Founding of the "Cornhill Magazine" (1970), and William E. Ames' A History of the "National Intelligencer" (1972).

Finally, studies covering the whole range of printing and publishing and allied fields in the United States, from the earliest to those published in 1969 and major works appearing early in 1970, are listed by wellconceived classes in G. Thomas Tanselle's impressive Guide to the Study of United States Imprints (1971).

\section{DesCriptive Bibliography}

Since the annual checklist compiled for Studies in Bibliography, on which this review is largely based, did not extend to bibliophily, book collecting, libraries, and librarianship (except to the extent that articles on those subjects appeared in the publications of bibliographical societies), consideration of those subjects must be omitted here. There remain to be considered notable examples of the application of the principles of descriptive bibliography published between 1949 and 1974, which fall in Class $\mathrm{M}$ in the scheme of $A B H B$ : Annual Bibliography of the History of the Printed Book and Libraries. American efforts, books and articles taken together, have been vigorous, and almost equally divided among English literature, American literature, American history, and other subjects. It is impossible to do more here than suggest, by example, the range and quality of the work accomplished.

\section{ENGLiSH AND AMERICAN LiteratURe}

In the field of English literature Charlton Hinman's The Printing and Proof-Reading of the First Folio of Shakespeare (1963) stands as proof of the valuable results that can be achieved by attention to detail in cases where the circumstances and the nature of the material justify the effort involved. Donald C. Gallup's T. S. Eliot: A Bibliography (rev. ed., 1969), Archibald Hanna, Jr.'s John Buchan, 1875-1940: A Bibliography (1953), and John J. Slocum and Herbert Cahoon's A Bibliography of
James Joyce (1882-1941) (1953) all deal comprehensively with a particular author. George H. Healey's The Cornell Wordsworth Collection (1957) and George L. McKay's six-volume catalog of the Stevenson Library . . . Formed by Edwin J. Beinecke (1951-1964) describe major collections in the hands of universities, as does Alexander D. Wainwright's Robert Louis Stevenson: A Catalogue of the Henry E. Gerstley Stevenson Collection (1971).

Any account of the bibliography of American literature since 1949 must begin with Jacob N. Blanck's Bibliography of American Literature (1955- ), which is now drawing to a close. The bibliographies of individual authors published in the past twenty-six years range from Thomas F. Currier's A Bibliography of Oliver Wendell Holmes (1953), edited by Eleanor M. Tilton, through Emily E. F. Skeel's A Bibliography of the Writings of Noah Webster (1958), edited by Edwin H. Carpenter, Jr., to Matthew J. Bruccoli's F. Scott Fitzgerald (1972) in the newly established Pittsburgh Series in Bibliography. Studies of special classes of literature have been as varied as Albert Johannsen's The House of Beadle and Adams and Its Dime and Nickel Novels (1950) and its supplemental volume of 1962; Lyle H. Wright's successive American Fiction, 1774-1850 (2d rev. ed., 1969), American Fiction, 1851-1875 (1957), and American Fiction, 1876-1900 (1966); Roger E. Stoddard's A Catalogue of Books and Pamphlets Unrecorded in Oscar Wegelin's "Early American Poetry, 1640 1820" (1969); and d'Alté A. Welch's A Bibliography of American Children's Books Printed Prior to 1821 (1972).

\section{AMERICAN HistoRy}

Among the important bibliographies to appear in the field of American history have been Robert W. G. Vail's Voice of the Old Frontier (1949), Thomas W. Streeter's Bibliography of Texas, already mentioned, and the eight volumes (1966-1970) of the catalog of the sale of his collection. This last stands head and shoulders above the usual auction catalog because of the inclusion of so many of Streeter's notes, written during the forty years and more in which the books were collected. Valerian Lada- 
Mocarski's Bibliography of Books on Alaska Published Before 1868 (1969) presents the early record of what is now the most northern of our states, and a group of striking works, including Neal Harlow's Maps of San Francisco Bay from the Spanish Discovery in 1769 to the American Occupation (1950), Lloyd A. Brown's Early Maps of the Ohio Valley: A Selection . . . from 1673 to 1783 (1959), and Carl I. Wheat's Mapping the Transmississippi West, 15401861 (1957-1963), gives us the geographical setting of American history.

\section{OTHer Subjects}

Other subjects as diverse as medicine (Robert B. Austin's Early American Medical Imprints . . . 1668-1820, 1961, and Francisco Guerra's American Medical Bibliography, 1639-1783, 1962), botany (Rachel McM. M. Hunt's Catalogue of Botanical Books [to 1800], 1958-1961, in her collection), tobacco (Sarah A. Dickson and Perry H. O'Neil's Tobacco: A Catalogue of the Books, Manuscripts and Engravings Acquired since 1942 in the Arents Tobacco Collection at the New York Public Library from 1507 to the Present, 1958-1969), alchemy (Ian MacPhail's Alchemy and the Occult: A Catalogue of Books and Manuscripts from the Collection of Paul and Mary Mellon. Given to Yale University Library, 1968), and religion (Margaret $\mathrm{T}$. Hills' The English Bible in America . . . $1777-1957,1961)$ have received careful attention.

\section{Conclusion}

A number of forces have contributed to the results summarized here. With the close of World War II there was a great increase in the collections of public and private libraries in the United States. The study of these collections produced an increased number of scholarly publications, for example those of the $\mathrm{Hu}$ manities Research Center at the University of Texas and those based on the Barrett Collection at the University of Virginia. The work of the Bibliographical Society of America, the Bibliographical Society of the University of Virginia, the Grolier Club, and other learned and bibliophilic societies, and grants from public funds and private foundations have assured interest and support for bibliographers. New periodicals devoted to publishing their work appeared, notable among them Studies in Bibliography (1948-1949 and following), just established at the start of our period, and Proof (1971), in its fourth volume at the close. During the same years the Papers of the Bibliographical Society of America has prospered and expanded. Although we have lost the Boston Public Library Quarterly, the Bulletin of the New York Public Library has been revived after a brief suspension, as has the Harvard Library Bulletin, and a number of college and university library periodicals have been established or enlarged.

All of these forces have had their effect, but in the end bibliography is the work of dedicated men and women. In the opening years of the period reviewed here scholars such as Harry Miller Lydenberg, Victor Hugo Paltsits, William Warner Bishop, and Clarence S. Brigham, whose careers had begun a half-century earlier, were still in the field. Fortunately, the tradition they followed has been carried forward. Last year brought us C. William Miller's Benjamin Franklin's Philadelphia Printing, 1728-1766: A Descriptive Bibliography (1974), in which every advance in bibliographical technique of the past twenty-six years has been brought to bear with admirable precision and results. This year has seen the publication of Edwin Wolf, 2nd's The Library of James Logan of Philadelphia, 1674-1751 (1975), which presents the most important of our early collectors and his books with wit and erudition. We may presently expect a new catalog of the Rosenwald Collection at the Library of Congress; the completion of the Bibliography of American Literature; volumes in the second hundred edited under the auspices of the Center for Editions of American Authors; and the 
appearance of the revised Short-Title Catalogue. With such work to its credit the United States may hope to make as full a contribution to bibliographical studies in the years ahead as it has in the past.

\section{REFERENCES}

1. The "Selective Check List" was continued in Studies in Bibliography through that for 1972 in volume 27 (1974). This paper is based on the twenty-four annual lists and the listing of publications of 1973 and 1974 in volumes 4 and 5 of $A B H B$ : Annual Bibliography of the History of the Printed Book and Libraries, edited by Hendrik D. L. Vervliet, scheduled for publication by Martinus Nijhoff at The Hague in 1975. The author acknowledges his debt to his colleagues in compiling the "Selective Check List" and the contribution of the United States to $A B H B$ : Lucy Clark and Fredson Bowers, who compiled "Part II: Later Renaissance to the Present" of the "Selective Check List" for 1949; Rudolf Hirsch, who compiled "Part I: Incunabula and the Early Renaissance" of the lists for 1949 through 1962; Derek A. Clarke, who was responsible for Part I for 1963 through 1972; and Rudolf Hirsch, who has joined him in compiling the contribution of the United States to $A B H B$. Finally, he is especially indebted to Dr. Hirsch for his kindness in reading the section of this paper dealing with incunabula in manuscript and making suggestions for its improvement.

2. Fredson Bowers, writing in the introduction to "A Selective Check List of Bibliographical Scholarship for 1949," Studies in Bibliography 3:292 (1950-51).

3. Stanley Pargellis, "Gesner, Petzholdt, et al," Papers of the Bibliographical Society of America 53:15-20 (1959).

4. ABHB: Annual Bibliography of the History of the Printed Book and Libraries, vol. 1, Publications of 1970, and following volumes; ed. by Hendrik D. L. Vervliet (The Hague: Martinus Nijhoff, 1973- ).

5. Curt F. Bühler, James G. McManaway, and Lawrence C. Wroth, Standards of Bibliographical Description (Philadelphia: Univ. of Pennsylvania Pr., 1949), p.70-73.

6. The lists for 1949 through 1954 were reprinted, with the addition of the list for 1955 and an index, as Studies in Bibliography, Decennial Extra Volume, volume 10 (1957). Those for the next seven years were reprinted, with an index, as Selective Check List of Bibliographical Scholarship, Series B, 1956-1962 (Charlottesville: Univ. Press of Virginia for the Bibliographical Society of the University of Virginia, 1966). The lists for 1963 through 1972 are to be found in the volumes of Studies in Bibliography from volume 18 (1965) through volume 27 (1974).

\section{BIBLIOGRAPHY}

Adams, Frederick B., Jr., comp. See CobdenSanderson, Thomas J.

Adams, W. C. "History of Papermaking in the Pacific Northwest," Oregon Historical Quarterly 52:21-37, 83-100, 154-85 (1951).

Albaugh, Gaylord P. “American Presbyterian Periodicals and Newspapers, 1752-1830, with Library Locations," Journal of Presbyterian History 41:165-87 (1963), and following volumes.

Alden, John. "Pills and Publishing: Some Notes on the English Book Trade, 1660-1715," Library, 5th ser. 7:21-37 (1952).

. Rhode Island Imprints, 1727-1800. New York: Bowker for the Bibliographical Society of America, 1950.

American Imprints Inventory Project. Wisconsin. A Check List of Wisconsin Imprints, 1864-1869. Madison, Wis.: State Historical Society of Wisconsin, 1953.

Ames, William E. A History of the "National
Intelligencer." Chapel Hill, N.C.: Univ. of North Carolina Pr., 1972.

Arndt, Karl J. R., and Olson, May E. Die deutschsprachige Presse der Amerikas, 17321968: Geschichte und Bibliographie. Pullach/ München: Verlag Dokumentation, 1973.

Austin, Robert B., comp. See U.S. National Library of Medicine.

Ayerst, David. The "Manchester Guardian": Biography of a Newspaper. Ithaca, N.Y.: Cornell Univ. Pr., 1971.

Baender, Paul. "The Meaning of Copy-Text," Studies in Bibliography 22:311-18 (1969).

Bald, R. C. "Editorial Problems-A Preliminary Survey," Studies in Bibliography 3:3-17 (1950-51).

Beaumont, Francis. The Dramatic Works in the Beaumont and Fletcher Canon. General editor Fredson Bowers. 2 vols. Cambridge: Univ. Pr., 1966-70.

Belknap, George W. McMurtrie’s “Oregon Im- 
prints": A Supplement. Portland, Oreg.: Binfords \& Mort, 1951.

- Oregon Imprints, 1845-1870. Eugene, Oreg.: University of Oregon Bookshop, 1968.

Bishop, William Warner. A Checklist of American Copies of "Short-Title Catalogue" Books. 2d ed. Ann Arbor, Mich.: Univ. of Michigan Pr., 1950.

Blanck, Jacob N. Bibliography of American Literature. Vol. 1-. New Haven, Conn.: Yale Univ. Pr., 1955- . Six volumes have been published from 1955 through 1973.

Bond, Richmond P. The "Tatler": The Making of a Literary Journal. Cambridge, Mass.: Harvard Univ. Pr., 1971.

Bowers, Fredson. Bibliography and Textual Criticism. Oxford: Clarendon Press, 1964.

-. "Bibliography, Pure Bibliography, and Literary Studies," Papers of the Bibliographical Society of America 46:186-208 (1952).

"Bibliography Revisited," Library, 5th ser. 24:89-128 (1969).

-. "Multiple Authority: New Problems and Concepts of Copy-Text," Library, 5th ser. 27:81-115 (1972).

- Principles of Bibliographical Description. Princeton, N.J.: Princeton Univ. Pr., 1949.

- "Purposes of Descriptive Bibliography, with Some Remarks on Methods," Library, 5th ser. 8:1-22 (1953).

"Some Principles for Scholarly Editions of Nineteenth-Century American Authors," Studies in Bibliography 17:223-28 (1964).

- "Some Relations of Bibliography to Editorial Problems," Studies in Bibliography 3:37-62 (1950-51).

- ed. See Beaumont, Francis; Crane, Stephen; Dekker, Thomas; and Whitman, Walt.

Brigham, Clarence S. Additions and Corrections to "History and Bibliography of American Newspapers, 1690-1820." Worcester, Mass.: American Antiquarian Society, 1961. Also in Proceedings of the American Antiquarian Society 71:13-62 (1961).

- 'American Booksellers' Catalogues, 1734-1800," in Essays Honoring Lawrence C. Wroth, p.31-67. Portland, Maine: Anthoensen Press, 1951.

- Paul Revere's Engravings. Worcester, Mass.: American Antiquarian Society, 1954.

Briquet, Charles Moïse. The New Briquet . . . C. M. Briquet Les Filigranes. . . A Facsimile of the 1907 Edition with Supplementary Material Contributed by a Number of Scholars. Edited by Allan Stevenson. 4 vols. Amsterdam: Paper Publications Society, 1968.

Bristol, Roger P. "Additions and Corrections to Bristol's Supplement to Evans," Proceedings of the American Antiquarian Society 82:4664 (1972).

-The American Bibliography of Charles Evans. Volume 14-Index. Worcester, Mass.: American Antiquarian Society, 1959.

- Index of Printers, Publishers, and Booksellers Indicated by Charles Evans in His "American Bibliography." Charlottesville, Va.: Bibliographical Society of the University of Virginia, 1961.

-. Index to "Supplement to Charles Evans' 'American Bibliography.' " Charlottesville, Va.: Univ. Press of Virginia for the Bibliographical Society of the University of Virginia, 1971.

- Supplement to Charles Evans" "American Bibliography." Charlottesville, Va.: Univ. Press of Virginia for the Bibliographical Society of America and the Bibliographical Society of the University of Virginia, 1970.

Brown, H. Glenn, and Brown, Maude C. A Directory of Printing, Publishing, Bookselling and Allied Trades in Rhode Island to 1865. New York: New York Public Library, 1958.

A Directory of the Book-Arts and Book Trade in Philadelphia to 1820, Including Painters and Engravers. New York: New York Public Library, 1950.

Brown, Lloyd A. Early Maps of the Ohio Valley: A Selection... from 1673 to 1783. Pittsburgh, Pa.: Univ. of Pittsburgh Pr., 1959.

Browne, Hablôt K. Phiz. Illustrations from the Novels of Charles Dickens, by Albert Johannsen. Chicago: Univ. of Chicago Pr., 1956.

Bruccoli, Matthew J. F. Scott Fitzgerald: A Descriptive Bibliography. Pittsburgh, Pa.: Univ. of Pittsburgh Pr., 1972.

- "The SCADE Series: Apparatus for Definitive Editions," Papers of the Bibliographical Society of America 67:431-35 (1973).

- and others. The Author's Intention. Washington, D.C.: Center for Editions of American Authors, 1972.

Bühler, Curt F. "Another View of the Dating of the Missale speciale Constantiense," $\mathrm{Li}$ brary, 5th ser. 14:1-10 (1959).

-. "The Constance Missal and Two Documents from the Constance Diocese," Papers of the Bibliographical Society of America 50:370-75 (1956).

- Early Books and Manuscripts. New York: Grolier Club, 1973.

-The Fifteenth-Century Book: The Scribes, the Printers, the Decorators. Philadelphia: Univ. of Pennsylvania Pr., 1960.

- "Last Words on Watermarks," Papers of the Bibliographical Society of America 67:1-16 (1973).

- The University and the Press in Fif- 
teenth-Century Bologna. Notre Dame, Ind.: Mediaeval Institute, University of Notre Dame, 1958.

- "Who Printed the Missale speciale Constantiense?" Book Collector 6:253-58 (1957).

; McManaway, James G.; and Wroth, Lawrence C. Standards of Bibliographical Description. Philadelphia: Univ. of Pennsylvania Pr., 1949.

Bush, Alfred L., comp. See Princeton University. Library. American Indian Periodicals.

Byrd, Cecil K. A Bibliography of Illinois Imprints, 1814-1858. Chicago: Univ. of Chicago Pr., 1966.

$\longrightarrow$, and Peckham, Howard H. A Bibliography of Indiana Imprints, 1804-1853. Indianapolis, Ind.: Indiana Historical Bureau, 1955.

Cahoon, Herbert. The Overbrook Press Bibliography, 1934-1959. Stamford, Conn.: Overbrook Press, 1963.

- joint author. See Slocum, John J.

Carpenter, Edwin H., Jr., ed. See Skeel, Emily E. F.

Charvat, William, joint author. See Tryon, Warren S.

Cobden-Sanderson, Thomas J. Bookbindings by T. J. Cobden-Sanderson: An Exhibition. Compiled by Frederick B. Adams, Jr. New York: Pierpont Morgan Library, 1969.

Cooper, Gayle. A Checklist of American Imprints for 1830. Metuchen, N.J.: Scarecrow, 1972.

Cornell University. Library. The Cornell Wordsworth Collection. Compiled by George Harris Healey. Ithaca, N.Y.: Cornell Univ. Pr., 1957.

Crandall, Marjorie L. Confederate Imprints: A Check List Based Principally on the Collection of the Boston Athenaeum. 2 vols. Boston: Boston Athenaeum, 1955.

Crane, Joan St.C. "Rare and Seldom-Seen Dust Jackets of American First Editions," Serif $7: 27-30,70-73$ (1970), and following volumes.

Crane, Stephen. The University of Virginia Edition of the Works of Stephen Crane. Edited by Fredson Bowers. Vol. 1-. Charlottesville, Va.: Univ. Press of Virginia, 1969Vols. 1, 4-9 published 1969-73.

Currier, Thomas F. A Bibliography of Oliver Wendell Holmes. Edited by Eleanor M. Tilton. New York: New York Univ. Pr., 1953.

Dawson, Muir. History and Bibliography of Southern California Newspapers, 1851-1876. Los Angeles: Dawson's Bookshop, 1950.

Dearing, Vinton A. A Manual of Textual Analysis. Berkeley, Calif.: Univ. of California Pr., 1959.

Principles and Practice of Textual
Analysis. Berkeley, Calif.: Univ. of California Pr., 1974.

Dekker, Thomas. The Dramatic Works of Thomas Dekker. Edited by Fredson Bowers. 4 vols. Cambridge: Univ. Pr., 1953-61.

Dickson, Sarah A., comp. See New York. Public Library. Arents Tobacco Collection.

Drake, Milton. Almanacs of the United States. 2 vols. New York: Scarecrow, 1962.

Eddy, Spencer L., Jr. The Founding of the "Cornhill Magazine." Muncie, Ind.: Ball State University, 1970.

Eisenstein, Elizabeth L. "The Advent of Printing and the Problem of the Renaissance," Past and Present 45:19-89 (1969).

. "Some Conjectures about the Impact of Printing on Western Society," Journal of Modern History 40:1-56 (1968).

Everitt, Charles P. Adventures of a Treasure Hunter. Boston: Little, 1951.

Faibisoff, Sylvia G., and others. "A Bibliography of Newspapers in Fourteen New York State Counties," New York History 52:190214 (1971), and following volumes.

Faye, Christopher U. Fifteenth Century Printed Books at the University of Illinois. Urbana, Ill.: Univ. of Illinois Pr., 1949.

Fleming, John F., joint author. See Wolf, Edwin, 2nd. Rosenbach.

Fraser, James H. "Indian Mission Printing: A Bibliography," New Mexico Historical Review 43:311-18 (1968).

- "Indian Mission Printing in Arizona: An Historical Sketch and Bibliography," Journal of Arizona History 10:67-102 (1969).

Fraser, Robert S., comp. See Princeton University. Library. American Indian Periodicals.

French, Hannah D. "The Amazing Career of Andrew Barclay, Scottish Bookbinder, of Boston," Studies in Bibliography 14:145-62 (1961).

. "Caleb Buglass, Binder of the Proposed Book of Common Prayer, Philadelphia, 1786," Winterthur Portfolio 6:15-32 (1970).

. "John Roulstone's Harvard Bindings," Harvard Library Bulletin 18:171-82 (1970).

- joint author. See Papantonio, Michael.

; Rogers, Joseph W.; and LehmannHaupt, Hellmut. Bookbinding in America. Reprinted, with bibliographical supplements. New York: Bowker, 1967.

Gallup, Donald C. T. S. Eliot: A Bibliography. rev. ed. London: Faber; New York; Harcourt, Brace \& World, 1969.

Gardiner, C. Harvey. Prescott and His Publishers. Carbondale, Ill.: Southern Illinois Univ. Pr., 1959.

Goff, Frederick R. "Early Printing in Georgetown (Potomak), 1789-1800," Proceedings 
of the American Antiquarian Society 68:10734 (1958).

- "The First Decade of the Federal Act for Copyright, 1790-1800," in Essays Honoring Lawrence C. Wroth, p.101-28. Portland, Maine: Anthoensen Press, 1951.

-. "The Four Florentine Editions of Savonarola's Predica dellarte del bene morire," New Colophon 3:286-301 (1950).

Incunabula in American Libraries: A Supplement to the Third Census. New York: Bibliographical Society of America, 1972.

. Incunabula in American Libraries: A

Third Census of Fifteenth-Century Books Recorded in North American Collections. New York: Bibliographical Society of America, 1964.

. The Permanence of Johann Gutenberg. Austin, Tex.: Humanities Research Center, University of Texas at Austin, 1971. , ed. See U.S. Library of Congress.

Goodhart, Howard Lehman. Fifteenth-Century Books in the Library of Howard Lehman Goodhart. With a Description and Check List by Phyllis Walter Goodhart Gordan. Stamford, Conn.: Overbrook Press, 1955.

Gordan, Phyllis Walter Goodhart, comp. See Goodhart, Howard Lehman.

Greenly, Albert H. A Bibliography of Father Richard's Press in Detroit. Ann Arbor, Mich.: William L. Clements Library, 1955.

Guerra, Francisco. American Medical Bibliography, 1639-1783. New York: Lathrop C. Harper, 1962.

Hamilton, Sinclair. See Princeton University. Library. Early American Book Illustrators.

Hanna, Archibald, Jr. John Buchan, 18751940: A Bibliography. Hamden, Conn.: Shoe String, 1953.

Haraszti, Zoltán. The Enigma of the Bay Psalm Book. Chicago: Univ. of Chicago Pr., 1956.

Hargrett, Lester. Oklahoma Imprints, 18351890. New York: Bowker for the Bibliographical Society of America, 1951.

Harlow, Neal. Maps of San Francisco Bay from the Spanish Discovery in 1769 to the American Occupation. San Francisco, Calif.: Book Club of California, 1950.

Harvard University. Library. Department of Graphic Arts. . .. Catalogue of Books and Manuscripts. Part I: French 16th Century Books. Compiled by Ruth Mortimer. 2 vols. Cambridge, Mass.: Harvard Univ. Pr., Belknap Press, 1964.

. . . Catalogue of Books and Manuscripts. Part II: Italian 16th Century Books. Compiled by Ruth Mortimer. 2 vols. Cambridge, Mass.: Harvard Univ. Pr., Belknap Press, 1974.

Harwell, Richard B. Confederate Imprints in the University of Georgia Libraries. Athens,
Ga.: Univ. of Georgia Pr., 1964.

More Confederate Imprints. 2 vols.

Richmond, Va.: Virginia State Library, 1957. (Supplements Marjorie L. Crandall's Confederate Imprints, entered above.)

Hatch, Benton L. A Check List of the Publications of Thomas Bird Mosher. Northampton, Mass.: Gehenna Press for Univ. of Massachusetts Pr., 1966.

Healy, George Harris, comp. See Cornell University. Library.

Heilbronner, Walter L. Printing and the Book in Fifteenth-Century England: A Bibliographical Survey. Charlottesville, Va.: Univ. Press of Virginia for the Bibliographical Society of the University of Virginia, 1967.

Hemphill, John M., II, joint author. See Samford, C. Clement.

Hewlett, LeRoy. "James Rivington, Tory Printer," in Books in America's Past, edited by David Kaser, p.166-93. Charlottesville, Va.: Univ. Press of Virginia for the Bibliographical Society of the University of Virginia, 1966.

Hills, Margaret T. The English Bible in America . . . 1777-1957. New York: American Bible Society and New York Public Library, 1961.

Hinman, Charlton. The Printing and ProofReading of the First Folio of Shakespeare. 2 vols. Oxford: Clarendon Press, 1963.

Hirsch, Rudolf. Printing, Selling and Reading, 1450-1550. Wiesbaden: Otto Harrassowitz, 1967.

. Printing, Selling and Reading, 14501550. Second Printing with a Supplemental Annotated Bibliographical Introduction. Wiesbaden: Otto Harrassowitz, 1974.

Hofer, Philip. Baroque Book Illustration: A Short Survey. Cambridge, Mass.: Harvard Univ. Pr., 1951.

Hoy, Cyrus. "On Editing Elizabethan Plays," Renaissance and Reformation 8:90-99 (1972).

Hunt, Rachel McM. M. Catalogue of Botanical Books in the Collection of Rachel McMasters Miller Hunt. 3 vols. Pittsburgh, Pa.: Hunt Botanical Library, 1958-61. Vol. 1, Printed Books 1477-1700, compiled by Jane Quinby; Vol. 2 in 2 vols., Introduction and Printed Books 1701-1800, compiled by Allan Stevenson.

Hunter, Dard. Papermaking by Hand in America. Chillicothe, Ohio: Mountain House Press, 1950.

. Papermaking in Pioneer America. Philadelphia: Univ. of Pennsylvania Pr., 1952.

Huss, Richard E. The Development of Printers' Mechanical Typesetting Methods, 18221925. Charlottesville, Va.: Univ. Press of 
Virginia for the Bibliographical Society of the University of Virginia, 1973.

Jackson, William A. "The Revised STC: A Progress Report," Book Collector 4:16-27 (1955).

Johannsen, Albert. The House of Beadle and Adams and Its Dime and Nickel Novels. 2 vols. Norman, Okla.: Univ. of Oklahoma Pr., 1950.

- The House of Beadle and Adams and Its Dime and Nickel Novels. Vol. 3, Supplement, Addenda, Corrigenda, etc. Norman, Okla.: Univ. of Oklahoma Pr., 1962.

- comp. See Browne, Hablôt K.

Kainen, Jacob. George Clymer and the Columbian Press. New York: The Typophiles; San Francisco, Calif.: Book Club of California, 1950.

Kaser, David. The Cost Book of Carey and Lea, 1825-1838. Philadelphia: Univ. of Pennsylvania Pr., 1963.

- A Directory of the St. Louis Book and Printing Trades to 1850. New York: New York Public Library, 1961.

. Joseph Charless: Printer in the Western Country. Philadelphia: Univ. of Pennsylvania Pr., 1963.

- Messrs. Carey \& Lea of Philadelphia. Philadelphia: Univ. of Pennsylvania Pr., 1957.

Katz, Joseph, joint author. See Meriwether, James B.

Keynes, Geoffrey, and Wolf, Edwin, 2nd. William Blake's Illuminated Books: A Census. New York: Grolier Club, 1953.

Klinefelter, Walter. "The ABC Books of the Pennsylvania Germans," Publications of the Pennsylvania German Society 7:1-104 (1973).

Korn, Bertram W. "Benjamin Levy: New Orleans Printer and Publisher," Papers of the Bibliographical Society of America 54:22164 (1960). Supplemented by his "Additional Benjamin and Alexander Levy Imprints," Papers of the Bibliographical Society of America 62:245-52 (1968).

Lada-Mocarski, Valerian. Bibliography of Books on Alaska Published Before 1868. New Haven, Conn.: Yale Univ. Pr., 1969.

Lazare, Edward J., comp. See Streeter, Thomas W. The Celebrated Collection of Americana, Index.

Lehmann-Haupt, Hellmut. Gutenberg and the Master of the Playing Cards. New Haven, Conn.: Yale Univ. Pr., 1966.

of L. Hart, 1950.

joint author. See French, Hannah D. Bookbinding in America.

-; Wroth, Lawrence C.; and Silver,
Rollo G. The Book in America. $2 \mathrm{~d}$ ed. New York: Bowker, 1951.

Liebert, Herman W. Bibliography Old \& New. Austin, Tex.: Humanities Research Center, University of Texas at Austin, 1974.

McCorison, Marcus A. Additions and Corrections to "Vermont Imprints, 1778-1820." Worcester, Mass.: American Antiquarian Society, [1968].

. Vermont Imprints, 1778-1820. Worcester, Mass.: American Antiquarian Society, 1963.

. "Vermont Papermaking, 1784-1820," Paper Maker 33, no. 1:19-28, no. 2: 23-31 (1964). And "Addenda," Vermont History 33:351-52 (1965).

MacCurdy, Raymond R. A History and Bibliography of Spanish-Language Newspapers and Magazines in Louisiana, 1808-1949. Albuquerque, N.Mex.: Univ. of New Mexico Pr., 1951.

McKay, George L., comp. See Yale University. Library. A Stevenson Library.

McManaway, James G., joint author. See Bühler, Curt F. Standards of Bibliographical Description.

MacPhail, Ian. Alchemy and the Occult: A Catalogue of Books and Manuscripts from the Collection of Paul and Mary Mellon. Given to Yale University Library. 2 vols. New Haven, Conn.: Yale University Library, 1968.

Magee, David B. Infinite Riches: The Adventures of a Rare Book Dealer. New York: P. S. Eriksson, 1973.

Magee, Dorothy, and Magee, David. Bibliography of the Grabhorn Press, 1940-1956, with a Check-List, 1916-1940. San Francisco, Calif.: Grabhorn Press, 1957.

Marston, Thomas E. See Yale University. Library. Incunabula.

Meriwether, James B., and Katz, Joseph. "A Redefinition of 'Issue.'” Proof 2:61-70 (1972).

Miller, C. William. Benjamin Franklin's Philadelphia Printing, 1728-1766: A Descriptive Bibliography. Philadelphia: American Philosophical Society, 1974.

Miner, Dorothy E. See Walters Art Gallery, Baltimore.

Mooney, James E., joint author. See Shipton, Clifford K. National Index of American Imprints.

Morrison, Paul G. Index of Printers, Publishers and Booksellers in ... "A Short-Title Catalogue . . . 1475-1640." Charlottesville, Va.: Bibliographical Society of the University of Virginia, 1950.

Mortimer, Ruth, comp. See Harvard University. Library. Department of Graphic Arts.

Mott, Frank Luther. A History of American 
Magazines. Vol. 4, 1885-1905. Cambridge, Mass.: Harvard Univ. Pr., 1957.

Nemoy, Leon, comp. See Yale University. Library. Incunabula.

New York. Public Library. Arents Tobacco Collection. Tobacco: A Catalogue of the Books, Manuscripts and Engravings Acquired since 1942 in the Arents Tobacco Collection... from 1507 to the Present. 10 pts., compiled by Sarah A. Dickson and Perry H. O'Neil. New York: New York Public Library, 195869.

Olson, May E., joint author. See Arndt, Karl J. R.

O'Neil, Perry H., comp. See New York. Public Library. Arents Tobacco Collection.

Paltsits, Victor Hugo, ed. See Stevens, Henry.

Pantzer, Katharine F. "The Serpentine Progress of the STC Revision," Papers of the Bibliographical Society of America 62:297-361 (1968).

Papantonio, Michael; with French, Hannah D.; Spawn, Carol M.; and Spawn, Willman Early American Bookbindings from the Collection of Michael Papantonio. New York: Pierpont Morgan Library, 1972.

Pargellis, Stanley. "Gesner, Petzholdt, et al.," Papers of the Bibliographical Society of America 53:15-20 (1959).

Parker, Wyman W. Henry Stevens of Vermont. Amsterdam: N. Israel, 1963.

Patterson, Lyman R. Copyright in Historical Perspective. Nashville, Tenn.: Vanderbilt Univ. Pr., 1968.

Peckham, Howard H., joint author. See Byrd, Cecil K. A Bibliography of Indiana Imprints.

Powell, John H. The Books of a New Nation: United States Government Publications, 1774-1814. Philadelphia: Univ. of Pennsylvania Pr., 1957.

Princeton University. Library. American Indian Periodicals in the Princeton University $\mathrm{Li}$ brary: A Preliminary List, by Alfred L. Bush and Robert S. Fraser. Princeton, N.J.: [Princeton University Library], 1970.

. Early American Book Illustrators and Wood Engravers, 1670-1870: A Catalogue of a Collection of American Books ... . in the Princeton University Library. With an Introductory Sketch . . . by Sinclair Hamilton. Princeton, N.J.: Princeton University Library, 1958.

- Early American Book Illustrators and Wood Engravers, 1670-1870: A Catalogue of a Collection of American Books .... in the Princeton University Library. Vol. 2, Supplement. Princeton, N.J.: Princeton Univ. Pr., 1968.

Robert Louis Stevenson: A Catalogue of the Henry E. Gerstley Stevenson Collection, the Stevenson Section of the Morris $L$.
Parrish Collection... and Items from Other Collections in the Department of Rare Books and Special Collections. Compiled by Alexander D. Wainwright. Princeton, N.J.: Princeton University Library, 1971.

Quinby, Jane, comp. See Hunt, Richael McM. M.

Randall, David A. Dukedom Large Enough. New York: Random, 1969.

Ray, Gordon N. "The Changing World of Rare Books," Papers of the Bibliographical Society of America 59:103-41 (1965).

. "The World of Rare Books Re-examined," Yale University Library Gazette 49: 77-146 (1974-75).

Rogers, Joseph W., joint author. See French, Hannah D. Bookbinding in America.

Rostenberg, Leona. The Minority Press and the English Crown: A Study in Repression, 1558-1625. Nieuwkoop: B. DeGraff, 1971.

, and Stern, Madeleine B. Old \& Rare: Thirty Years in the Book Business. New York: Abner Schram, 1974.

Samford, C. Clement, and Hemphill, John M., II, Bookbinding in Colonial Virginia. Charlottesville, Va.: Univ. Press of Virginia for Colonial Williamsburg, 1966.

Schullian, Dorothy M., comp. See U.S. Armed Forces Medical Library.

Shaw, Ralph R., and Shoemaker, Richard H. American Bibliography: A Preliminary Checklist for 1801[-1819]. 20 vols. and 3 vols. of indexes, corrections, and addenda. New York: Scarecrow, [1958-1966].

Shipton, Clifford K. The American Bibliography of Charles Evans . . . Volume 13, 17991800. Worcester, Mass.: American Antiquarian Society, 1955.

- and Mooney, James E. National Index of American Imprints through 1800: The Short-Title Evans. 2 vols. Worcester and Barre, Mass.: American Antiquarian Society and Barre Publishers, 1969.

Shoemaker, Richard H. A Checklist of American Imprints for 1820[-1829]. 10 vols., the last four compiled with the assistance of Gayle Cooper, and 2 vols. of indexes by M. Frances Cooper. New York [and Metuchen, N.J.]: Scarecrow, 1964[-1973].

, joint author. See Shaw, Ralph R.

Siebert, Frederick S. Freedom of the Press in England, 1476-1776. Urbana, Ill.: Univ. of Illinois Pr., 1952.

Silver, Rollo G. The American Printer, 17871825. Charlottesville, Va.: Univ. Press of Virginia for the Bibliographical Society of the University of Virginia, 1967.

. "Efficiency Improved: The Genesis of the Web Press in America," Proceedings of the American Antiquarian Society 80:325-50 (1970). 
Typefounding in America, 1787-1825. Charlottesville, Va.: Univ. Press of Virginia for the Bibliographical Society of the University of Virginia, 1965.

, joint author. See Lehmann-Haupt, Hellmut. The Book in America.

Skeel, Emily E. F. A Bibliography of the Writings of Noah Webster. Edited by Edwin $\mathrm{H}$. Carpenter, Jr. New York: New York Public Library, 1958.

Slocum, John J., and Cahoon, Herbert. A Bibliography of James Joyce (1882-1941). New Haven, Conn.: Yale Univ. Pr., 1953.

Sommer, Francis E., comp. See U.S. Armed Forces Medical Library.

Sowerby, E. Millicent. Rare People and Rare Books. London: Constable, 1967.

Spawn, Carol M., and Spawn, Willman. "The Aitken Shop: Identification of an EighteenthCentury Bindery and Its Tools," Papers of the Bibliographical Society of America 57: 422-37 (1963).

—. "Francis Skinner, Bookbinder of Newport: An Eighteenth Century Craftsman Identified by His Tools," Winterthur Portfolio 2:47-61 (1965).

, joint authors. See Papantonio, Michael.

Spear, Dorothea N. Bibliography of American Directories through 1860. Worcester, Mass.: American Antiquarian Society, 1961.

Spell, Lota M. Pioneer Printer: Samuel Bangs in Mexico and Texas. Austin, Tex.: Univ. of Texas Pr., 1963.

Stern, Madeleine B. Imprints on History: Book Publishers and American Frontiers. Bloomington, Ind.: Indiana Univ. Pr., 1956.

, joint author. See Rostenberg, Leona.

Stevens, Henry. Recollections of James Lenox. Edited by Victor Hugo Paltsits. New York: New York Public Library, 1951.

Stevenson, Allan. Observations on Paper as Evidence. Lawrence, Kans.: University of Kansas Libraries, 1961.

. The Problem of the "Missale speciale." London: The Bibliographical Society, 1967.

- comp. See Hunt, Rachel McM. M. ed. See Briquet, Charles Moïse.

Stillwell, Margaret B. The Awakening Interest in Science During the First Century of Printing. New York: Bibliographical Society of America, 1970.

The Beginning of the World of Books, 1450 to 1470 . New York: Bibliographical Society of America, 1972.

. Incunabula in American Libraries: A Second Census of Fifteenth-Century Books Owned in the United States, Mexico, and Canada. New York: Bibliographical Society of America, 1940.

Stoddard, Roger E. A Catalogue of Books and Pamphlets Unrecorded in Oscar Wegelin's
“Early American Poetry, 1640-1820." Providence, R.I.: Friends of the Library of Brown University, 1969. Also in Books at Brown 23: 1-84 (1969).

- "Further Addenda to Wegelin's Early American Poetry," Papers of the Bibliographical Society of America 65:169-72 (1971).

Streeter, Thomas W. Bibliography of Texas, 1795-1845. 5 vols. Cambridge, Mass.: Harvard Univ. Pr., 1955-60.

The Celebrated Collection of Americana Formed by the Late Thomas W. Streeter. 7 vols.; and a volume of Index compiled by Edward J. Lazare. New York: ParkeBernet Galleries, 1966-70.

Strouse, Norman $\mathrm{H}$. The Passionate Pirate [Thomas Bird Mosher]. North Hills, Pa.: Bird \& Bull Press, 1964.

Sutton, Walter. The Western Book Trade: Cincinnati as a Nineteenth-Century Publishing and Book-Trade Center. Columbus, Ohio: Ohio State Univ. Pr. for Ohio Historical Society, 1961.

Tanselle, G. Thomas. "The Bibliographical Description of Paper," Studies in Bibliography 24:27-67 (1971).

- "The Bibliographical Description of Patterns," Studies in Bibliography 23:71-102 (1970).

. "Bibliography and Science," Studies in Bibliography 27:55-89 (1974).

- "Book-Jackets, Blurbs, and Bibliographers," Library, 5th ser. 26:91-134 (1971).

"Copyright Records and the Bibliographer," Studies in Bibliography 22:77-124 (1969).

Guide to the Study of United States Imprints. 2 vols. Cambridge, Mass.: Harvard Univ. Pr., Belknap Press, 1971.

- "The Identification of Type Faces in Bibliographical Description," Papers of the Bibliographical Society of America 60:185202 (1966).

2. "The Meaning of Copy-Text: A Further Note," Studies in Bibliography 23: 191-96 (1970).

- "The Periodical Literature of English and American Bibliography," Studies in Bibliography 26:167-91 (1973).

. "The Recording of Press Figures," Library, 5th ser. 21:318-25 (1966).

- "A System of Color Identification for Bibliographical Description," Studies in Bibliography 20:203-34 (1967).

-. "The Use of Type Damage as Evidence in Bibliographical Description," $\mathrm{Li}$ brary, 5th ser. 23:328-51 (1968).

Taylor, Archer. Book Catalogues: Their Varieties and Uses. Chicago: Newberry Library, 1957.

Catalogues of Rare Books: A Chapter 
in Bibliographical History. Lawrence, Kans.: University of Kansas Libraries, 1958.

A History of Bibliographies of Bibliographies. New Brunswick, N.J.: Scarecrow, 1955.

Tebbel, John. A History of Book Publishing in the United States. Vol. 1, The Creation of an Industry, 1630-1865. New York: Bowker, 1972.

Thompson, Lawrence S. "Hand Bookbinding in the United States since the Civil War," Libri 5:97-121 (1954).

Thorpe, James E. Principles of Textual Criticism. San Marino, Calif.: Huntington Library, 1972.

Tilton, Eleanor M., ed. See Currier, Thomas F.

Todd, William B. "Bibliography and the Editorial Problem in the Eighteenth Century," Studies in Bibliography 4:41-55 (1951-52).

- "Observations on the Incidence and Interpretation of Press Figures," Studies in Bibliography 3:171-205 (1950-51). (1953)

Tryon, Warren S., and Charvat, William. The Cost Books of Ticknor and Fields and Their Predecessors, 1832-1858. New York: Bibliographical Society of America, 1949.

U.S. Armed Forces Medical Library. A Catalogue of Incunabula and Manuscripts in the Army Medical Library, by Dorothy M. Schullian and Francis E. Sommer. New York: H. Schumann, 1949.

U.S. Library of Congress. The Rosenwald Collection: A Catalogue of Illustrated Books from Celebrated Presses, and of Bindings and Maps, 1150-1950, the Gift of Lessing $J$. Rosenwald to the Library of Congress. Edited by Frederick R. Goff. Washington, D.C. [The Library of Congress,] 1954.

U.S. National Library of Medicine. Early American Medical Imprints . . . 1668-1820, by Robert B. Austin. Washington, D.C.: Public Health Service, 1961.

Vail, Robert W. G. Voice of the Old Frontier. Philadelphia: Univ. of Pennsylvania Pr., 1949.

Wainwright, Alexander D., comp. See Princeton University. Library. Robert Louis Stevenson: A Catalogue.

Walters Art Gallery, Baltimore. The History of Bookbinding, 525-1950 A.D.: An Exhibition. Edited by Dorothy Miner. Baltimore, Md.: Trustees of the Walters Art Gallery, 1957.

Weber, Carl J. The Rise and Fall of James Ripley Osgood. Waterville, Maine: Colby College Press, 1959.

Welch, d'Alté A. A Bibliography of American Children's Books Printed Prior to 1821.
Worcester and Barre, Mass.: American Antiquarian Society and Barre Publishers, 1972.

Wheat, Carl I. Mapping the Transmississippi West, 1540-1861. 5 vols. San Francisco, Calif.: Institute of Historical Cartography, 1957-63.

Whitman, Walt. Whitman's Manuscripts: "Leaves of Grass" (1860), A Parallel Text. Edited by Fredson Bowers. Chicago: Univ. of Chicago Pr., 1955.

Wing, Donald G. Short-Title Catalogue ... 1641-1700. 3 vols. New York: Columbia Univ. Pr. for Index Society, 1945-51.

- Short-Title Catalogue ... 1641-1700. $2 d$ ed. rev. and enl. Vol. 1-. New York: Index Committee of the Modern Language Association, 1972-

Wolf, Edwin, 2nd. A Check-List of the Books in the Library Company of Philadelphia in and Supplementary to Wing's "Short-Title Catalogue, 1641-1700." Philadelphia: Library Company of Philadelphia, 1959.

- "Evidence Indicating the Need for Some Bibliographical Analysis of American Printed Historical Works," Papers of the Bibliographical Society of America 63:251-77 (1969).

The Library of James Logan of Philadelphia, 1674-1751. Philadelphia: Library Company of Philadelphia, 1974 [i.e., 1975].

- joint author. See Keynes, Geoffrey.

- , and Fleming, John F. Rosenbach: A Biography. Cleveland, Ohio: World, 1960.

Wright, Lyle H. American Fiction, 1774-1850. $2 \mathrm{~d}$ rev. ed. San Marino, Calif.: Huntington Library, 1969.

- American Fiction, 1851-1875. San Marino, Calif.: Huntington Library, 1957.

- American Fiction, 1876-1900. San

Marino, Calif.: Huntington Library, 1966.

Wroth, Lawrence C. Abel Buell of Connecticut. rev. ed. Middletown, Conn.: Wesleyan Univ. Pr., 1958.

- joint author. See Bühler, Curt F. Standards of Bibliographical Description; and Lehmann-Haupt, Hellmut. The Book in America.

Wust, Klaus G. "German Printing in Virginia: A Check List, 1789-1834," Report of the Society for the History of the Germans in Maryland 28:54-66 (1953).

Yale University. Library. Incunabula in the Yale University Libraries, by Thomas E. Marston with Leon Nemoy. New Haven, Conn.: Yale University Library, 1955.

- A Stevenson Library: Catalogue of a Collection . . . Formed by Edwin J. Beinecke. Compiled by George L. McKay. 6 vols. New Haven, Conn.: Yale University Library, 1951-64. 
Keep your

departments

up-to-date with

the everchanging

periodicals world.

\section{- Binding \\ - Reference}

- Serials Records

\section{They all need Faxon's}

\section{Serials Updating}

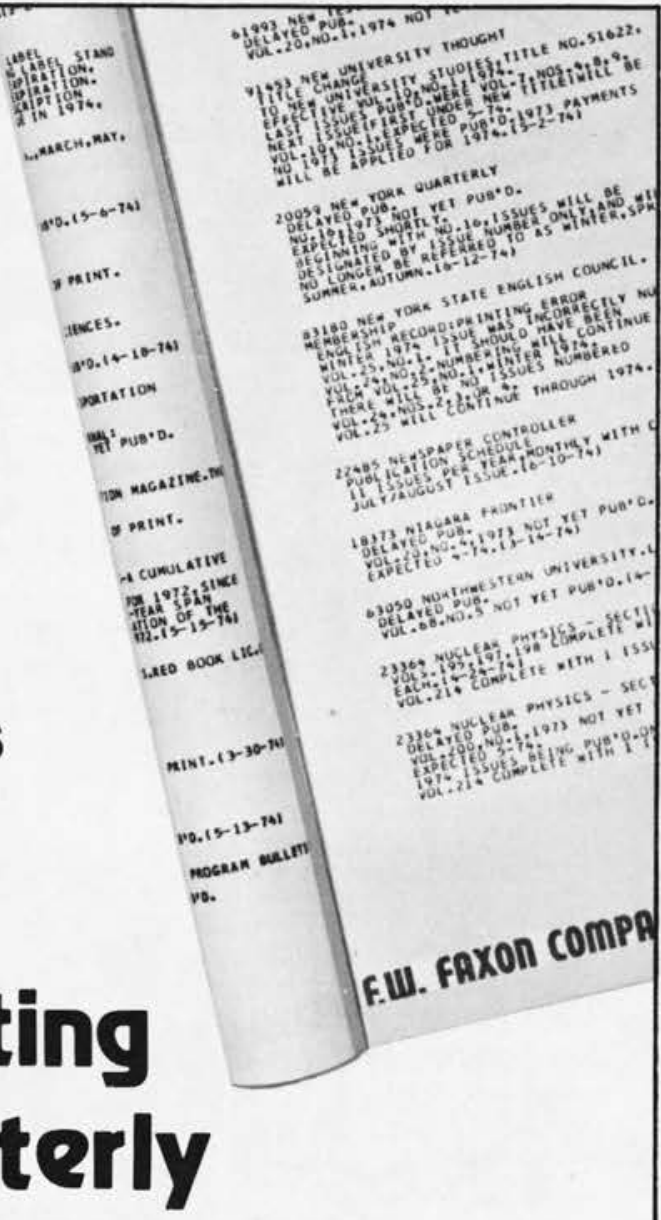

a quarterly newsletter containing the most current information on various serials titles. All changes (title, frequency, etc.) and bibliographic irregularities (additional volumes, delays in publication, etc.) are reported as Faxon is made aware of them. Each issue contains an average of 650 entries. A full-year subscription costs only $\$ 7.00$; two-years $\$ 13.50$; three-years $\$ 20.00$. Throughout the year, special issues containing additional information that Faxon feels will be of value to librarians will be offered to subscribers at no additional cost. A special Membership Issue is planned for 1975 . Sample copies are available on request.

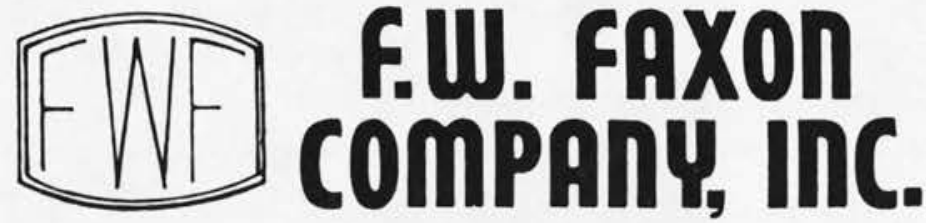

PUBLISHING DIVISION

15 SOUTHWEST PARK, WESTWOOD, MASS. 02090 


\section{Announcement}

\section{Silent Pilgrimage to God}

The Spirituality of Charles de Foucauld

"The brilliant, virile spirituality of Father Charles de Foucauld is highlighted in an anonymously edited book called Silent Pilgrimage to God. What de Foucauld sowed and what God has blessed was the fruit of his meditation and his love for the Eucharist. The book is so good that one is tempted to keep on quoting."

The Priest

(Sept.)

Cloth $\$ 4.95$

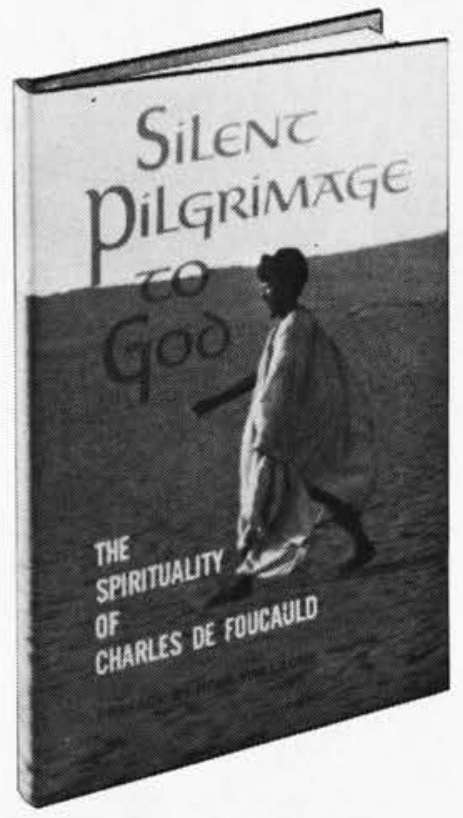

\section{Reaping the Green Revolution} by Sudhir Sen

"A masterwork, especially vital in the context of the global food crisis today. Its scope is extraordinary, for it both analyzes the nature of the food problem and offers specific guidance for solutions to apparently intractable problems." Dr. Ralph Buultjens, The New School for Social Research

(Oct.)

Cloth $\$ 10.95$

\section{Polygamy Reconsidered} by Eugene Hillman

Hillman sheds new light, not only on the attitudes of the Christian Churches toward African polygamy, but on their current reassessment of the full meaning of human sexuality as well.

(Nov.) Paper $\$ 7.95$, Cloth $\$ 15.00$

\section{Living Faith and Ultimate Goals}

Edited by S.J. Samartha

Christian, Hindu, Jewish, Muslim Buddhist, Marxist contributors voice their convictions about the ultimate meaning of life.

(Sept.)

Paper $\$ 3.95$
The Humanity of Man by Edmond Barbotin

A profoundly simple effort to help us rediscover the joy and glory of being human in a dehumanizing age.

(Aug.)

Cloth $\$ 12.95$

\section{Prayer at the Heart of Life}

by Pierre-Yves Emery

This book grew out of a series of discussions between Emery and young couples concerned with how prayer made any sense in our increasingly urbanized and technological society.

(Sept.)

Cloth $\$ 4.95$ 